
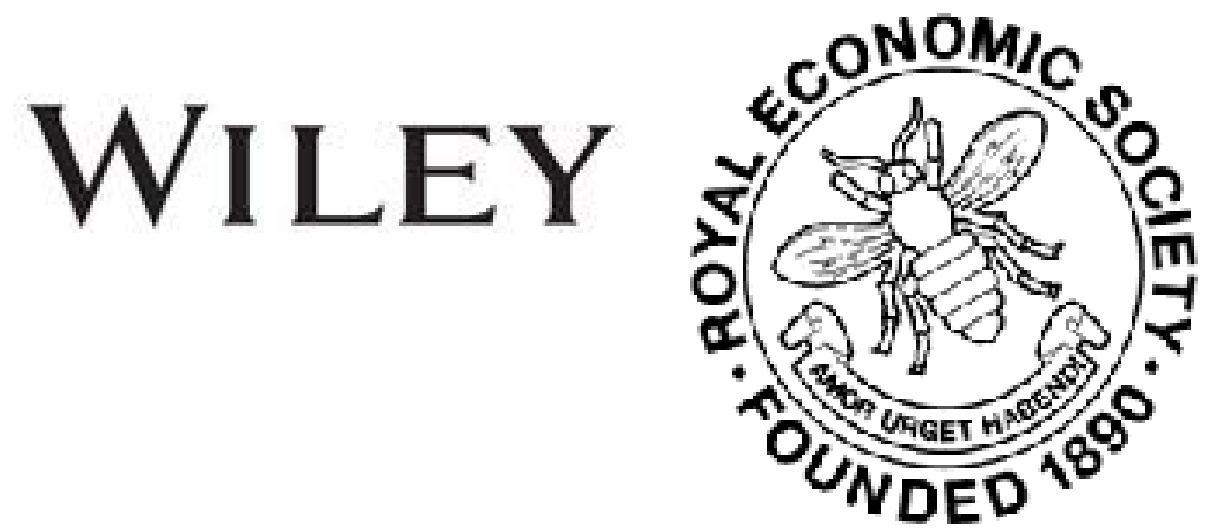

Some English Railway Problems of the Next Decade Author(s): T. C. Farrer

Source: The Economic Journal, Vol. 1, No. 2 (Jun., 1891), pp. 351-359

Published by: Wiley on behalf of the Royal Economic Society

Stable URL: http://www.jstor.org/stable/2956254

Accessed: 28-06-2016 13:55 UTC

Your use of the JSTOR archive indicates your acceptance of the Terms \& Conditions of Use, available at

http://about.jstor.org/terms

JSTOR is a not-for-profit service that helps scholars, researchers, and students discover, use, and build upon a wide range of content in a trusted digital archive. We use information technology and tools to increase productivity and facilitate new forms of scholarship. For more information about JSTOR, please contact support@jstor.org.

Wiley, Royal Economic Society are collaborating with JSTOR to digitize, preserve and extend access to The Economic Journal 


\section{SOME ENGLISH RAILWAY PROBLEMS OF THE NEXT DECADE}

The publication of the Board of Trade Return relating to overtime on our English Railways, and the disastrous Scotch strikes, ${ }^{1}$ have directed public attention to the administration of these great enterprises, which have become a vital part of the daily life of every Englishman.

There is undoubtedly a growing feeling that some change is necessary in the present organization, as it has proved unable to prevent the loss and misery of the strike.

Now that the jubilee of the world's railroad system is past, and that the main arteries of traffic are definitely constructed in all the older countries of the world, it ought to be possible to collect enough facts to make some generalisations with regard to the policy of our English system, to see where our shortcomings lie, and to suggest certain principles upon which improved methods of administration might be founded. Unfortunately, the very conditions of the railroad problem are so various and so constantly changing, that even the best books on railroad policy, such as Hadley's Railroad Transportation (Putnams), need to be brought up to date.

We have therefore to ask ourselves at the beginning, What are the conditions which the public may fairly ask that a private railroad system like ours should fulfil in 1891, remembering that, as regards the main arteries of traffic at any rate, our system is practically complete.

For the sake of clearness I will attempt to arrange these conditions under four headings, and discuss how far they can be carried out without injustice.

1 There was an equally bitter and almost equally protracted strike in Ireland last year, but as no evictions were involved, the picturesque correspondent was conspicuous by his absence, and the London newspapers ignored it almost entirely. 
We must from the first remember that our railway corporations differ from all Continental systems, inasmuch as the Government, i.e., the taxpayer, has not had to contribute one penny towards their construction or working, and that they have been built up on the theory that Government is not to interfere in their commercial or technical administration more than is absolutely necessary for the protection of the public.

They pay moreover $£ 2,000,000$ in the shape of rates and taxes, and this is only one of the instances which show what an enormous saving in capital to the country our private system has been.

The total capital sunk in the railways of Great Britain as compared to the National Debt, was, in April, 1890, in round figures as follows :-

$$
\begin{array}{llll}
\text { Railway Capital } & \ldots & \ldots & £ 876,595,000 . \\
\text { National Debt } & \ldots & \ldots & £ 689,944,000 .
\end{array}
$$

I think that these figures are enough to prove that we may leave out of consideration, in this paper, the question of State purchase, since it would more than double the National Debt. Returning then to the question of the duties of these semi-monopolists to the public, we may put them under the following heads :-

1 Publicity of Rates and Tariffs.

2 Performance of Contract, e.g., Punctuality.

3 Reasonable Facilities and steady Progress.

4 Fair Treatment of Individuals-

(1) Among the Public,

(2) Among the Employees.

\section{1.-PUBLICITY OF RATES AND TARIFFS.}

I have put this subject first, because, in my opinion, publicity is a far better remedy for most of the grievances of the public against the railroads than any laws. What the trader wants to know is the maximum that he may be called on to pay, and also to be sure that no secret rebate, of which he knows nothing, is made to his competitor in business. The Americans have coined a phrase which expresses this well, viz., 'personal discrimination.'

Competition necessitates practically that there shall be differential rates, i.e., that the rates cannot be fixed exclusively on a mileage basis, but this is a very different thing to a personal rebate. 
Every committee that has investigated the subject has admitted, not only in this country, but in America, in France, and in Italy, that 'equal mileage rates' are impossible and disastrous. Bismarck, in the height of his power, when he took over the Prussian roads, thought to institute a logical system based on equal mileage, but failed completely.

The particular case was, that Austrian corn used to have very much lower through export rates to North Sea ports over Prussian roads than the Prussian local rates, and Bismarck cut off these through rates. The traffic at once found its way over the Austrian roads to the Mediterranean ports, or down the Elbe by water, and the Prussian railways lost the traffic, so that the Prussian State Railway managers found their receipts sinking enormously, and would have had to recoup themselves by raising the local rates.

The old system had to be reverted to, and the old system was economically right. For, whereas, the Prussian local corn rates paid the railways an interest, of say, 5 per cent. over working expenses, the foreign corn paid an interest also, though it might be only 2 per cent., and this 2 per cent. would not have been touched at all, had the lower rate not been granted.

Every London shopkeeper probably does the same thing in selling one article at a profit of 10 per cent., and another at a price which gives him a bare 1 per cent.

If the principle be once admitted as fair, the object of insuring publicity in rates is clear. It is that the differential rate may be justified by the company on fair and logical grounds, and not on the grounds of favour.

Without such publicity, i.e, without being bound to give open reasons (which, if necessary, must afterwards be made good in a court of law), any unscrupulous goods manager might get hold of competitive traffic by personal discrimination, or more than this, one town or district might be favoured at the expense of another.

It would seem from the evidence of Mr. Findlay, General Manager of the London and North Western Railway, before the Railway Rates Tribunal of last year, that the great majority of railway men admit the principle of publicity, and have abandoned the untenable standpoint of the Liberty and Property Defence League, viz., that a railway company is a purely private concern, whose directors may deal exactly as they please with the public in the matter of rates, without being bound to furnish any explanation of apparent anomalies.

No. 2.-VoL. I

A A 


\section{2.-PERFORMANCE OF CONTRACT-e.g. PUNCTUALITY.}

This is a point, to which in my opinion, not nearly enough attention has been devoted in this country by the higher railway intelligence; probably owing to the system of competition which has led one railway, though with a longer route, to attempt to do the distance in the same time as the shorter railway, even when in practice it is impossible. Had the courts originally held that the time table was a contract and the fare or part of the fare was recoverable if the contract was broken, our present gross unpunctuality, as exemplified in the returns presented to Parliament last year, would never have existed. But as the law at present stands a passenger can only recover against a company if he shows special pecuniary damage, after a long and elaborate legal process. $^{1}$

Speaking as a railway man, I believe habitual unpunctuality to be quite unnecessary, and also, from the railway point of view, that it is most extravagant.

As it is a point of great interest to the public, and will undoubtedly be much discussed during the next decade, it may be worth while to consider a few of the technical reasons why in France a late train should be the exception, and in England the rule.

The principal reason is that in France the locomotive department is entirely subordinate to the traffic department (which arranges the time table), in fact, as a French director expresses it, the locomotive department is only cocher de fiacre.

In England, on the other hand, the traffic department is usually separate, and hạs absolutely no control over the locomotives or their drivers; the locomotive department being a completely distinct establishment. Possibly this is a relic of the extraordinary strong personality of George Stephenson, who was par excellence a ' locomotive man.'

In England, drivers get a valuable premium on coal saved, and it is in consequence not to their interest to make up time lost at stations or signals; in France they also get such a premium, but they get treble this premium for running punctually.

The consequence is that day after day you may see the French

1 It would of course be unfair to alter the law now, since our present train-service has grown up on another basis, but I believe that had punctuality originally been insisted upon in this way, our traffic would have been conducted with practical exactitude, though somewhat less speed. 
express from Paris (which goes at exactly the same speed as the English train) arrive to the moment at Calais pier.

It is idle to pretend nowadays that our speeds are the cause of lateness, since some of our fastest trains keep the best time.

Moreover abroad almost all railway engineers go through some months' training in the traffic department, so that they know from experience what are the requirements for punctual working. Thus in France, round the large towns, arrangements are universal for keeping the main lines entirely free from being crossed or interfered with by local traffic.

In England, competition, with its untold advantages, is yet responsible for much delay. For instance, through carriages and horse boxes are attached for individuals to almost any train, whereas in other countries they are rigorously confined to a few slow trains. Almost any company will stop an express for a few people if the traffic is competitive, though the eight or ten minutes so lost inconvenience perhaps hundreds of ordinary passengers.

As some railways do keep practically exact time, I go so far as to say that the public have a right to demand punctuality from the companies who are offenders; and further, I believe that it would be enormously to the financial advantage of these companies if they were compelled to keep time. I do not believe that the public need lose any privileges worth considering, since those companies which are now punctual do not grant less facilities than others.

For instance, it is absurd to allege, as some railway men do, that our practice of booking up to the last moment is responsible for serious delays, since trains hardly ever start late from this cause. In the South of England 75 per cent. of the delays arise from signals (which may mean bad administration or overcrowded lines), or from time lost at roadside stations, which is a fault of administration, or from the locomotive, the. reasons for which have been explained above.

\section{3.-REASONABLE FACILITIES AND STEADY PROGRESS.}

A railway system which does not make steady progress is not satisfactory.

It may fairly be asked, Does our organization in England provide for moving with the times? and give reasonable security for keeping touch with public opinion? To answer these questions in any absolute way is impossible. But it may be doubted if the extraordinary divergence between our best and worst companies

A A 2 
is altogether re-assuring on this point. How is it to be provided that the worst should level up to the best and not vice versâ ?

How is any district to protect itself against arbitrary action on the part of a board of directors? The answer is not clear. From the one man system of the United States we are, happily for our country, almost free. The usual organization of an English railway consists of a board of directors, who retain a general control, the executive being in the hands of the general manager, whose powers however vary very greatly on different lines.

The chairman may or may not interfere in executive detail. It appears as if the tendency were that he should not so interfere, but that committees of the board should be formed to supervise the various sections of the administration of the railway, dealing through the heads of departments and more especially through the general manager.

The questions of interest for the public are-

How is such a Board to escape petrifaction or senility?

What security is given that experiments shall be tried?

How can it be arranged that financial-even possibly Stock Exchange considerations-shall not overrule the primary duties of a railway company to its district?

It seems that the English system, on the larger companies at any rate, has escaped the evils suggested in these questions to a wonderful extent.

English public opinion is so focused, and the press so strong that the gross financial swindles of America are unknown.

The railways, too, have been largely constructed with money subscribed in the district through which they pass, so that a good deal of pressure can be and is exercised by local shareholders. But the fact remains that a body of shareholders is a very bad and a very weak constituency.

The great danger seems to be the want of expansion or fresh ideas in administration. There are plenty of engineering schools, but no railway schools in the country. There is no real railway club, no first-rate railway paper published in the country. The difference on the other side of the Atlantic is great. Fresh ideas are welcomed, and some of the most acute minds in the United States have devoted themselves to the theory of railroading. All technical questions are discussed there with a freedom from obstinate or conservative prejudice which is quite refreshing. The public take an appreciative interest in technical railway improvements, and understand that the primary object of a railway is to carry passengers and goods as cheaply and as well as possible. 
Their directorates differ from ours, inasmuch as-if not the president, then the vice-presidents are men of technical knowledge, who have spent years in learning their business, and yet have not allowed detail to swamp their general views; nor are they overburdened with administrative minutiæ as are our officers.

It seems highly probable that some change in the nature of representation on the boards of directors of the districts served must come in this country. Our larger systems have on the whole been so honestly and admirably managed by the men who built them up out of a great quantity of small local lines that the cry for this has not yet arisen; especially as the plan has been followed of selecting local directors from various districts through which the railways pass ; but with the end of the building of new competitive lines, and with the growing demand for democratic local self-government, it is clear that some change of the sort will be made.

In Prussia, where the organization of the State railroads has been carried out as well as possible, each local State railway board has on it members representing the commercial interests of the district, subject of course to the central office at Berlin.

I am bound to add that the plan has not abolished a system of red tape administration which would be intolerable to Englishmen.

The greatest safeguard which this country possesses, however, is in the potential competition which exists. No monopoly is permitted to become absolute in this country, and the possible competitor is the one thing which keeps all semi-monopolists from abuse of their power.

The sea, too, according to the Report of the Royal Commission of 1872, affects three-fifths of our railway rates, and it is unlikely that railway companies will be allowed to acquire many more harbours; or that many amalgamations among themselves on parallel lines will now be sanctioned. It should always be remembered in defence of our system of administration by boards, that if one railway in any district goes to sleep, owing to the age or incapacity of its direction, it is highly probable that its neighbour will be slightly more awake, and the loss of competitive traffic is a reminder even to the most legarthic trading corporation.

Those who have seen the transformation of the Lancashire and Yorkshire from one of the least to one of the most enterprising companies, will admit the wisdom of Parliament in refusing to sanction its amalgamation with even the immaculate London and North Western Railway some eighteen years ago. 


\section{4.-FAIR TREATMENT-OF INDIVIDUALS AMONG THE PUBLIC; OF INDIVIDUAL EMPLOYEES.}

The individual in this country has always been considered of more importance than the mass.

The great safeguard, which, with regard to railways, he still has to rely on, is the stimulating effect of competition.

In France, where the railways are guaranteed monopolies, the common law is much more severe against the companies in respect to delays, loss, claims, etc., than here, but few Englishmen would like to exchange our system for theirs. The greatest cause of grievance-viz., secret rebates, I have already spoken of above.

But with regard to employees, the case is somewhat different. The power and wealth of the greatest corporations is so enormous, that they are veritable states within a state.

For instance the whole National Debt of Holland stands as follows in regard to the capital of the London and North Western Railway.

Whole debt of Holland, $1890 \quad$ - $\quad$ - $\quad$ - $£ 90,487,000$

Capital of L. \& N. W. Railway, 1890 - $-£ 103,755,000$

While discipline is and must be strict, the employees ought to have some protection against anything like personal tyranny. Probably publicity and perfectly fair trial is the best remedy that can be suggested. My friend, Mr. Acworth, has pointed out to me that in the service where discipline has to be most strictly maintained, viz., in the army, the latest-joined subaltern can appeal against his colonel to a court-martial, and a fair trial is always insured.

I do not for a moment mean to insinuate that it is the wishit is certainly not the interest-of the Companies, to treat their servants unfairly, but I believe it would lead to better results, if the old view of secrecy in these matters were abolished, and a more public system of trial, punishments, and inquiries into alleged grievances could be instituted.

I am convinced from experience that many cases of useless labour, for instance of station-masters, to take a particular example, could be remedied, if it were not for the jealousies of various departments at head-quarters, who all insist on the unfortunate station-master obeying each of their departmental orders.

If there were a registered "court of inquiry" the appeal to which should not in any way make an employee a " marked man" this sort of thing could be stopped at once, and it would be to the advantage of the company that it should be stopped. 
The labour troubles of to-day however raise too large a question to be discussed here. They seem to be growing more bitter, perhaps owing to the fact that the enormous extension of joint stock business has made the personal contact of masters and men almost impossible, and there is no reason why the Board of a Joint Stock Company should be philanthropic, if the members are not large minded enough to see that it is to their interest to have a contented staff. I do not, myself, see how any profit-sharing scheme can be applied to railroads, though the practice of facilitating investment in railway stocks by employees is largely increasing. I believe that the management of the staff must more nearly approach that of the Post Office, or the Army, than of a societe en commandite, since the capital invested is too enormous for the employees to own any considerable share.

In concluding this section of our subject, one cannot but feel that railway men are now so well paid, and their position is so well assured, that some modus vivendi ought to be found which would prevent disastrous strikes. It has been suggested that a court of arbitration might be instituted, two of whose members should be government officials, to be called in as assessors on the request of either party.

To sum up, we may admit that as our private railway system was the first to be constructed, so was it the first to lead the world, in speed, in accommodation, and in cheapness.

To keep this proud position it is in need of constant criticism, and the publicity necessary to such criticism, and moreover, of intelligence to enable us to keep a foremost place in technical matters.

From the age of construction we are are moving into an age when working, or what the French call 'exploitation' will be more important: and how far our system will meet this change remains to be seen. But as government purchase is out of the question, and as the change has to be met, it will be for the public to demand what they need, and to call attention to improvements in the methods of other nations; and these our companies, if their future is at all like their past, should assuredly not be slow to introduce.

T. C. FARRER 